\title{
Trends in Urban Morphological Data Capture: A Review of Theoretical Perspectives on Utility of Geospatial Technology
}

\author{
Maurice Onyango Oyugi \\ Department of Architecture and Building Science, University of Nairobi, Nairobi, Kenya
}

Email address:

maurice.oyugi@uonbi.ac.ke

\section{To cite this article:}

Maurice Onyango Oyugi. Trends in Urban Morphological Data Capture: A Review of Theoretical Perspectives on Utility of Geospatial Technology. American Journal of Remote Sensing. Vol. 8, No. 1, 2020, pp. 20-34. doi: 10.11648/j.ajrs.20200801.12

Received: August 1, 2019; Accepted: September 27, 2019; Published: May 18, 2020

\begin{abstract}
Increasing urbanisation and sub-optimal locations of urban amenities and utilities has resulted in many cities facing environmental, land use and socio-economic challenges. This can be mitigated by the implementation of cost-effective urban development plans and policies together with an in-depth understanding of the interactions existing between urban natural and human systems, an undertaking reliably aided by geospatial technologies notably Remote Sensing, Geographical Information Systems, Global Positioning System and Photogrammetry. Over the year, this has enabled geospatial technology to gain primacy in the urban study areas such as the modelling of urban morphology, development of urban plans and in the study of other urbanization phenomena such as heat balance, air quality and transportation management among others. However, the accuracy, validity and reliability of the by-products of such operations are dependent on the quality of the datasets used. This paper is therefore anchored on an understanding of urban morphology, factors determining its changes over time and demonstrated achievements of the utility of geospatial technology in the study of the same. The paper concludes with policy implications for the applications of the geospatial technology in urban studies.
\end{abstract}

Keywords: Urban Morphology, Geospatial Technology, Data Capture, Urban Planning, Land Use, Land Cover

\section{Introduction}

Cities are dynamic in response to their environmental afflictions over time. However, a review of urban research in the developing countries reveals that even though research proposals in the 1990s prioritised urbanisation and allied environmental topics, there is scanty evidence of those researches having been completed and disseminated [37]. This was occasioned by inadequacy of data in addition to poor analytical frameworks for understanding the magnitude and trends of urbanisation as well as how the phenomenon relates to global warming and climate change. However, the problem may be mitigated through adoption of geospatial information systems - a terminology encompassing Satellite Remote Sensing, Geographical Information Systems (GIS), Global Navigation Satellite systems, Cartography and Photogrammetry. The technology enables mapping of urban morphological parameters as well as modelling the relationship existing between urbanisation and environmental quality conditions such as air quality and surface temperature values, the prediction of the impact of urbanisation and allied anthropogenic activities on biodiversity, climate change and global warming whose mitigation are imperative in the realisation of sustainable human settlements, economic development, improvements in human health and minimisation of land use conflicts among others.

Geographical Information Systems is a geospatial system designed to capture, manipulate, store and manage georeferenced data for the solution of spatial problems. Data inputs for GIS are satellite remote sensing imageries, Photogrammetry and Global Positioning System products [21, 66]. The technology can be traced to more than 200 years ago when Alexander von Humboldt introduced the science of Geography which views the world as consisting of series of interrelated and interdependent processes. The first application of the GIS concept was made in the year 1832 when Charles Picquet created a map depicting the distribution of cholera outbreak across 48 districts of Paris 
[39]. Similarly, John Snow adopted the technique in the year 1854 to understand the causes of cholera in London. While Horticulturist and Landscape Architect Warren Manning used map overlays to integrate various physical and cultural factors for site planning, Ian McHarg popularized Humboldt's and Manning's ideas in his 1969 publication Design with Nature [19]. Photo-zincography, a printing technique that was developed in the $20^{\text {th }}$ Century enabled the separation of map layers and provided an opportunity for the advancement of GIS as evidenced by the works of Waldo Tobler who is regarded as the first geographic information scientist [16]. Waldo Tobler used quantitative methods, computer algorithms and software tools to model geographic processes. In the 1960s, Roger Tomlinson conceptualised and built the first GIS in Canada while Carl Steinitz, an Urban Planner at Harvard University, pioneered many of the early ideas about the application of GIS for landscape analysis and urban planning [23, 38, 99]. The GIS concepts advanced in the 1970 s and 1980 s to witness the uptake of the technology by national agencies and institutionalization of the same by universities into academic discipline. Other developments have been witnessed in GIS software developments and their commercialization as corroborated by Esri - the software company that developed ArcView. While the focus of the technology has been on the provision of services, management of assets and gathering of the business intelligence among others, its frontiers have since shifted to data sharing across multiple platforms.

On the other hand, developments in Photogrammetry and the launch of the Landsat satellite system in the year 1972 began a period of major advances in the science and technology of remote sensing. Further to the above, advancements in computer technology in both hardware and software, developments in computer-aided cartography and graphics, new sources of geographic information such as the Global Positioning System and high-resolution satellite imageries and influx of internet technology have revolutionized spatial data collection and processing to support numerous applications and geospatial decision-making. The availability of geospatial data in digital form has facilitated three-dimensional geospatial simulations which are crucial for urban morphological analysis [44]. While the utility of geospatial techniques in the study of urban morphology finds its usefulness in its ability to integrate remote sensing, photogrammetric, cartographic and other ancillary data with GIS, the accuracy, validity and reliability of the by-products of such operations are dependent on the quality of the datasets used. For example, remote sensing data depending on the type of platform and sensor used have shortcomings occasioned by spatial and spectral resolutions required for the analysis of various urban morphological parameters. Currently, scientists are utilising the geospatial technology to collect and manage spatial data, measure, model and visualise spatial relationships, monitor urban environmental changes by establishing the nature, magnitude, trends and patterns of such changes. This has made the technology more relevant and appropriate in sustainable urban development.

\subsection{Objective of the Paper}

The purpose of this paper is to review the trends in the application of geospatial technology in urban morphology data capture and studies.

\subsection{Problem Statement}

This paper is guided by the question on how the challenge of insufficient spatial data required for urban morphological and management inquiries can be alleviated? The dearth of various research findings and reviews in this domain of knowledge provides justification for the paper.

\section{Method and Materials}

This review was guided by critical thinking research approach, which involves analysis of relevant literature on a phenomenon to enable researchers draw conclusion (s) on whether a claim is true, sometimes true, partly true or false. Critical thinking utilises observation, interpretation, inference, context skills, evaluation, explanation, meta-cognition, logic and applicable theoretical constructs for understanding the problem and the research question at hand to discern judgement. Other methods applied in critical thinking include broad intellectual criteria such as clarity, credibility, accuracy, precision, relevance, depth, significance and fairness [30]. The literature analyzed herein entails theoretical basis on urban morphological differentiation and the utility of geospatial techniques in the study of the same. To arrive at the conclusion, various arguments advanced by scholars are subjected to evaluation on their validity, reliability, logic and coherence.

\section{Literature Review}

\subsection{The Determinants of Urban Morphological Differentiations}

The concept of urban morphology was first expressed in the writings of the Poet and Philosopher Johann Wolfgang von Goethe in the year 1790. Since then, the term has been used in Geography, Urban Planning, Architecture and other related disciplines. Scholars have defined the concept depending on the focus of their studies. For example, Gilliland and Gauthier [42] define urban morphology as the study of a city's physical form which consists of development density, land use, street patterns and building configuration while Moudon [73] defines urban morphology as the study of a city as a human habitat. Despite diverse definitions of urban morphology by various scholars, an area of convergence is that an analysis of a city's morphology should begin with dissection of how the city has evolved over time and space, identification of the urban elements and transformations which have taken place on the elements as well as how the physical form produces various social forms [82]. Urban morphology has since evolved to discern the physical approach into a body of knowledge analysing the 
urban fabric as a means of understanding the urban structure [72]. This approach challenges the perception of urban centres as chaotic organic environments. According to Moudon [73], urban morphologists focus on socio-economic forces moulding cities through constant transformation of elements notably the buildings, gardens, streets, parks and monuments. This portrays cities as unconscious products that emerge over a long period of time through accrual of successive generations of developments which leaves traces that restructure the urban elements by either providing opportunities or constraints to successive developments. This has led many scholars to prefer the term urban morphogenesis to describe the field of study and the logic of these traces.

Three schools of thought exist in the study of urban morphology namely; the Italian, the British and the French [88]. The Italian school of thought dates from the year 1940s and is centred on the works of Saverio Muratori who attempted to develop an operational history for the cities he studied. This was meant to provide rationale for the integration of new architectural works in the syntax of the urban tissue [31]. Muratori's views were further advanced by Gianfranco Caniggia who conceptualised a city as a dynamic procedural typology of buildings, gardens, streets, parks and monuments shaped by political and economic force [33]. The British school of thought is centred on the works of M. R. G Conzen, who developed a technique called town-plan analysis [73]. For Conzen, understanding the urban building fabric and land use through history is imperative in comprehending the urban morphology. This approach has been applied by his followers such as J. W. R Whitehand and Peter Hall in the management of historic and contemporary townscapes. The realisation that the relationship existing between the built spaces and the social world is dialectical made the French school of thought based at the Versailles School of Architecture to place emphasis on the importance of built spaces in sustaining social practices. In America, urban morphology as a field of study owes its origins to Lewis Mumford, James Vance and Sam Bass Warner. Indeed, a realistic study of urban morphology need to fuse together the three schools of thought and must begin with critical review of the origin of a city and subsequent explanatory variables for the urban landscape tissues.

Postulations have been made on the determinants of urban morphology. Miller [70] posits that human behaviour impacts on urban morphology through city design. This view is shared by Hall [46] who argues that the management interventions adopted by cities have destroyed the entrepreneurship that was once the significant determinant of urban morphology. Sentiments expressed by Hall [46] have found expression in urban planning as a practice through the adoption of development corridor concept which entails the transformation of urban thoroughfares into linear business hubs. This concept works well if augmented with the concept of the city of towers which advocates for urban vertical densification as was advanced by Le Corbusier in the 1920s. Therefore, the entrepreneurial endeavour of the urban community determines urban morphological differentiation.
Bid rent theory posits that land uses compete for locations closer to the city centre due to the comparative advantage offered by the city centre in terms of accessibility, agglomeration economies and realisation of higher profits. As such, land uses within the inner city pays more rent which declines as one moves away from the city centre. In this regard, only land uses which are able to afford higher rents such as commercial enterprises offering high order goods and services will locate within the city centre and vice-versa. Therefore, rental differential is an imperative factor explaining urban land use differentiations [96].

Alonzo's [1] explanatory model of land use as expressed in Figure 1 gives an account of urban morphological differentiation based on land values. The model details out how households faced with the desire to buy land is equally faced with the dilemma of deciding on the size of land to purchase and how close it should be to the city centre. The model assumes a city of single employment and shopping centre with equal transportation opportunities and costs in all directions, making the cost of commuting to the city centre a function of the distance. The model also assumes that the households and firms have perfect knowledge of the prices of land within different locations of the city and that the cost of land drops as one moves away from the city centre. Therefore, household's locational equilibrium is achieved through selective combination of the desired quantity of land and distance from the city centre. Alonzo [1] further uses the concept of bid rent curve to arrive at distances from the city centre at which different land uses will viably locate. The model observes that the most accessible sites in the city goes to the users with the steepest bid rent-curve notably the high order commercial activities while users with the second steepest bid rent-curve locates on the next ring outward from the city centre. This compels land uses such as residential developments whose bid-rent curves are gentle to locate in the peripheries.

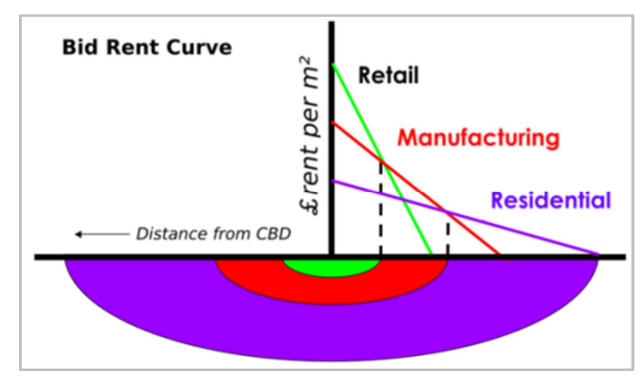

Source: Simon et al., [92]

Figure 1. Alonzo's Explanatory Model of Land Use.

Wingo [109] postulated Transportation-Oriented Theory to explain the distribution of urban residential development densities. The theory posits that higher residential development densities within cities positively correlate with accessibility. Webber [104] posits that spatial interactions (the flow of people, goods and services) as aided by transportation network are significant determinants of urban activities and spatial structure. Guttenberg [45] advances the 
concept further by acknowledging that accessibility influences urban morphology by promoting interactions and land use clustering. However Firey [35], in his study of Boston city observes that socially rooted values and ethnicity exert causative influence on urban land use patterns and that infrastructure and market forces are only secondary factors. Therefore, failure to recognize the role of cultural values in determining urban land use differentiation by Wingo [109], Alonzo [1], Webber [104] and Guttenberg [45] was an omission.

The concentric, sector and multi-nucleic models illustrated by Figure 2 are the descriptive models commonly used to explain land use differentiations within a city. The concentric-model postulated by Burgess [18] consists of five series of concentric zones namely; the Central Business District (CBD), Zone of Transition, Working Men's Homes, Residential Zone and the Commuters' Zone. Burgess [18] notes that while the CBD has facilities such as shopping areas, theatres, hotels, offices and banks among others, the zone of transition is characterised by mixed land uses such as the co-existence of high-rise residential developments with commercial developments. The zone of working men's homes is home to factory workers while the residential zone is where the white-collar workers and middle-income families reside. The fifth ring being the commuters' zone is a suburban community where the upper-income group having private modes of transport reside. Burgess [18] further observes that with increasing urbanisation, inner zones invade the next outer zones similar to ecological succession. In contrast, when urban decay occurs, the outer zones remain stationary while inner fringe of the transitional zone recedes into the CBD. While the model provides a useful explanation to urban land use patterns, it is an oversimplification of urban morphological reality.

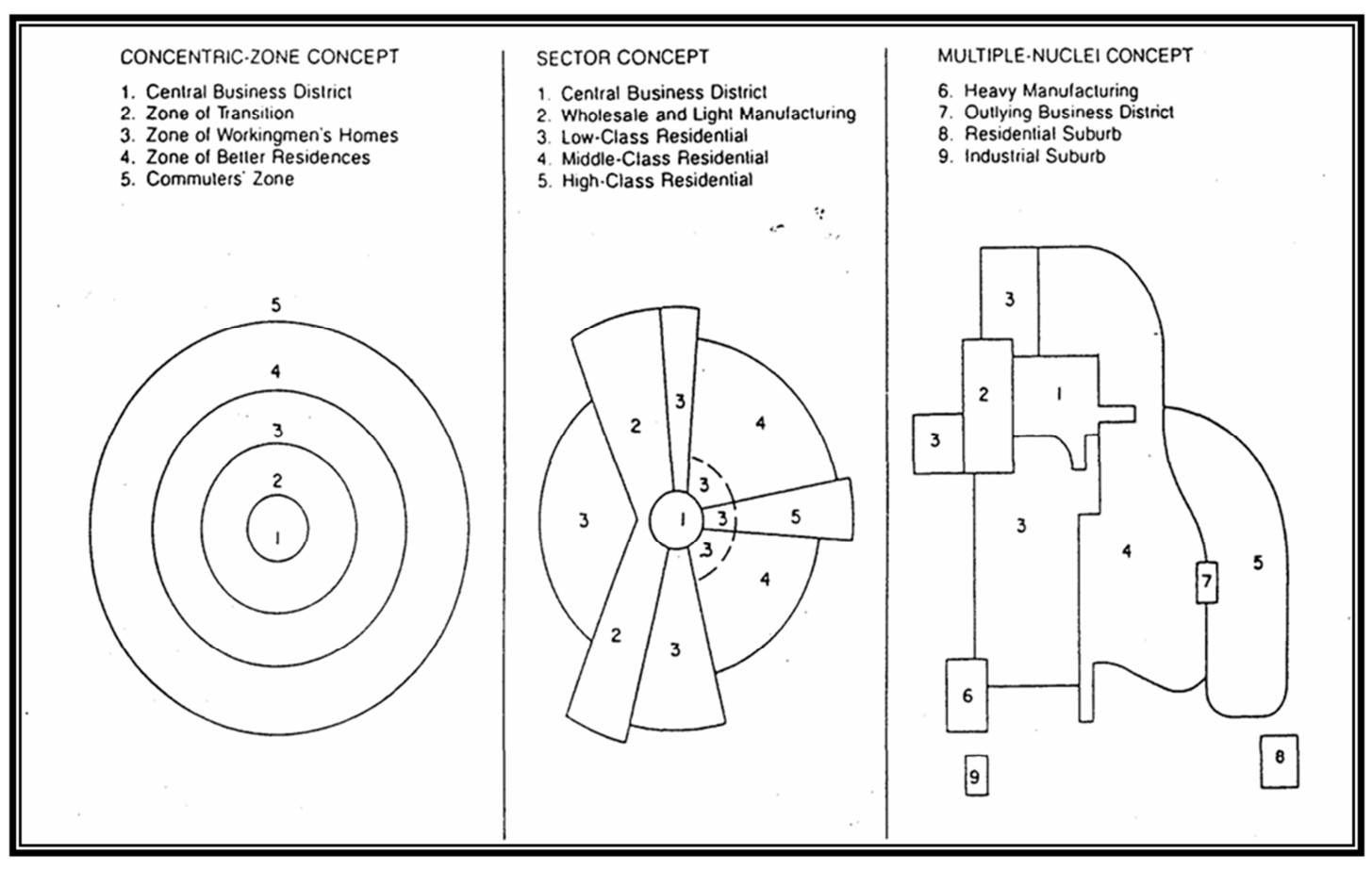

Source: Hartshon [48]

Figure 2. Descriptive Urban Land Use Models.

Hoyt [53] postulated the sector model which posits that different urban land uses locate in distinct neighbourhoods in a star-shaped manner centred on a single CBD which is the most accessible part of a city. Rents then graduate downwards from the CBD as determined by transportation network. In this case, high-income residential areas developing along the highways pull high order commercial activities to the neighbourhoods to form an agglomeration of compatible land uses. Despite the simplicity of the model and its emphasis on residential developments, it provides a profound explanation to urban land use differentiations than the concentric model. Harris and Ullman [47] formulated multi-nucleic model which posits that rather than a single $\mathrm{CBD}$ as postulated by other models, there exist series of nuclei patterning urban land uses. The nuclei may take the form of industrial or wholesaling centres where specialized complementary economic activities have gravitated over the years. Harris and Ullman [47] further note that factors responsible for multi-nucleic patterning of urban land uses are interdependent of certain activities, thus they find it mutually profitable to cluster. Some activities have specific site requirements which must be fulfilled for them to locate. Presence of activities which are offensive to other users and rents which either attract or repel users. Despite the model satisfactorily explaining the metropolitan land use differentiations, it needs modification before it can be utilised in explaining land use differentiations in cities with colonial origin which has continued to influence land uses post the era. 
As noted by the $19^{\text {th }}$ century scholars such as Ruskin, Geddes, Carlyle, Dickens, Engels and Disraeli, urban land use differentiations are occasioned by land value speculations and environmental considerations [40]. This informed Howard [52] to envisage a town with communal land ownership where residential facilities and civic buildings are distributed along a large central court with shopping centres and industrial land uses located on the edges. As illustrated in Figure 3, Howard's utopian city envisaged a population of 58,000 people within 1,000 acres surrounded by 5,000 acres of agricultural land. Suburbanisation theory as postulated by Knox and Linda [56] has recently been used to explain urban land use differentiation and sprawl. The theory states that urban sprawl manifesting through increased built-up, open and transitional areas to the urban peripheries is occasioned by relatively cheaper land and construction costs in the peripheries. This is also accentuated by increased public investments in infrastructure notably; roads, water and electricity in what used to be urban peripheries consequently improving quality of life and attracting more people into the neighbourhoods. Another factor which contributes to suburbanisation is the persistent higher property and business taxes in the city centre. Since property and business taxes in the peripheries are relatively low, businesses which can no longer break even in the city centre are pushed to the peripheries where they agglomerate into new satellite commercial districts. This enables large proportion of the city's inhabitants to reside and work in the peripheries to reduce transport costs to and from work [43]. For example, Babarinde [7] in his study of industrial migration and residential relocation in Lagos, a mega-city in Nigeria, having a population of approximately 17 million, found out that manufacturing firms in congested inner-city areas were relocating to the peri-urban areas where they could enjoy access to larger production sites at cheaper costs. However, the study observed that as distance from the CBD increases, the number of workers who relocated with their employerfirms began to decrease due to several factors notably; housing shortage in Lagos and cultural attachment to their homes and relatives. Hence, many workers would prefer to continue living in the inner-city. This finding resonates with Firey's [35] findings in his study of Boston city. In the process, the emergent sub-urban landscape can have important policy implications for the mega-city in terms of housing and infrastructure expansion to accommodate workers who might have to relocate or stay put at their original locations.

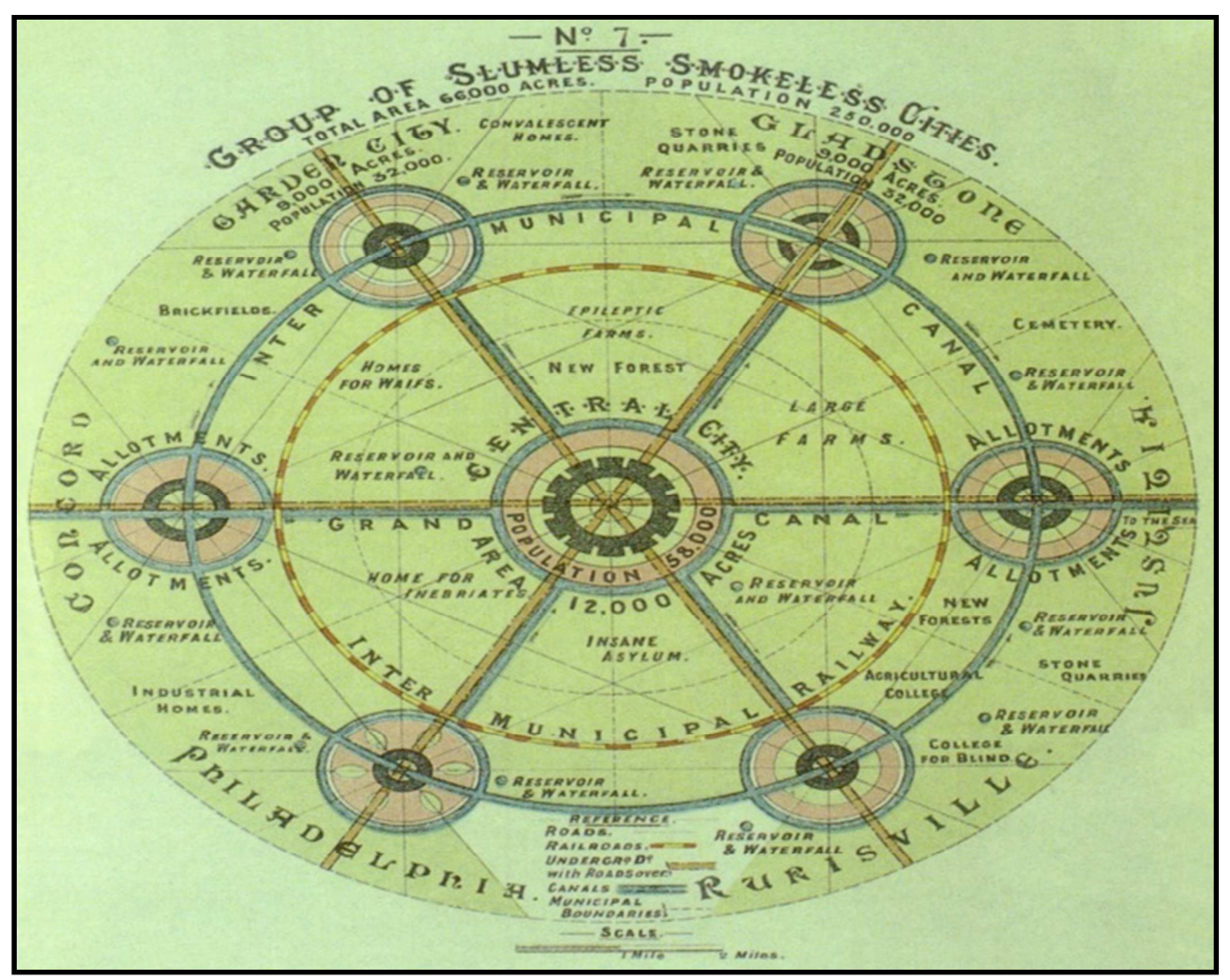

Source: Gallion [40]

Figure 3. Ebenezer Howard's Model.

The suburbanisation theory is further linked to labour aristocracy theory which is anchored on labour mechanism and urban bias theories. Labour mechanism theory posits that there exist dualistic (modern and traditional) economy and wide wage differentials between urban (modern economy) and rural (traditional economy) areas of the developing nations, making labour to migrate to the urban areas with anticipation of high wages [56]. Urban bias theory postulated 
by Lipton [59] posits that governments tend to invest and concentrate modernization projects such as electricity, piped water, good housing and telephony in urban areas. This attracts rural population to migrate to the urban areas to enjoy the privileges hence abandoning the rural areas but end up finding the contrary, forcing them to seek alternative accommodation in the urban peripheries. This accentuates land use transformations from agricultural to built-up land uses such as residential, commercial and industrial users.

Bicik et al [10] postulate that urban land use dynamics is a by-product of the interactions between nature and the society's socio-economic developments. While Bibby and Shepherd [9] posit that the rate of urban land use change is determined by the demand and supply of houses, population growth, political ideology and the national economic performance, Bourne [14] suggests that the main processes controlling urban land use dynamics are the expansion of urban infrastructure especially transportation and the migration of industrial, institutional, commercial and recreational land uses to the suburbs. Bourne [14] further postulates that population increase alone is no longer the main stimulus of urban land use dynamics. This debate has metamorphosed into sustainable urban development agenda of the $21^{\text {st }}$ century which incorporates multiple-variables such as natural ecology, socio-economic, political and legal factors in explaining land use differentiations within a city.

De Groot et al [25] advances the debate on sustainable urban development by noting that urban land use equilibrium is achieved through perceptions among the urban residents as to whether an urban neighbourhood provides a healthy environment for interactions and establishment of economic activities. If the perception is negative, then there is likelihood of migration and establishment of the activities in other neighbourhoods, which are positively perceived. This ultimately leads to urban land use changes. De Groot et al [25] further states that urban vibrancy depends on the ability of an urban centre to provide goods and services to its inhabitants which trigger land use changes. Other sentiment expressed by De Groot et al [25] on the same argument is that legal, statutory regulations, political decisions on land use and technological advancements in the society accelerate urban land use changes. Together with the above, globalisation which facilitates movement of people, goods and services between nations also determines the urban morphological changes depending on a city's location, internal site opportunities and the stage of national economic development.

According to Mengistu and Salami [69], physiographic conditions and geo-processes such as climatic and pedological variations, tectonic forces, drainage regime and the socio-economic drivers comprising of technological and demographic changes, social values such as property rights, economic growth, political and public policies on land use are the main agents of land use and land cover changes. In support of this argument, Arvind and Nathawat [4] in their study of land use and land cover mapping of Panchkula, India using multi-date satellite imageries observed that heterogeneous climate and physiographic conditions in the district had resulted in the development of different land use and land cover categories. Similar sentiments are also expressed by Mwathi [77], Broitman and Koomen [15] and Asoka et al [5] who postulate that population growth, income levels, a city's physiographic attributes, land supply and access, taxation, development policies and enforcement framework as well as technology and political goodwill influence urban land use changes.

Museleku [76] in the study of causes and effects of agricultural land use conversions in the urban fringes of Nairobi city, Kenya concludes that the rapid and haphazard conversions experienced in the city's fringes are occasioned by low returns from agriculture, increased urban population, high demand for housing facilities and ineffective management framework for regulating agricultural land use conversions. Similar conclusions are also arrived at by Maina [65] and Kirigwi [55]. While Mundia and Aniya [74] posit that urbanisation is accompanied by urban sprawl, Oyugi et al [84] concludes that the sprawl is exacerbated by a city's economic growth rate and development, demographic and physiographic base as well as transportation network. In support of the above, Kumar and Sangwan [58] observe that urbanisation triggers urban land use transformation through its influence on urban population growth, sprawl and economic development. Other studies with similar conclusions include Musa and Odera [75], Lo and Yang [61], Samie et al [87], Benti et al [8], Xiangmei et al [111] and Finger [34] among others.

\subsection{An Appraisal of the Role of Geospatial Techniques in Urban Morphological Studies}

The efficiency and effectiveness of geospatial technology has enhanced its utility in urban morphological studies in comparison to conventional surveying methods of mapping which are labour intensive, time consuming and unreliable in capturing spatiotemporal aspects of rapidly changing urban environments [11, 54]. Shosheng and Kutiel [91] undertook a comparative study on the utility of geospatial and conventional surveying techniques in deriving information on land use and land cover variations and concluded that geospatial techniques are cost effective and efficient owing to the technology's ability to instantaneously acquire data of large and inaccessible areas. The increased computer power over the years has further enhanced processing of the satellite imageries, making satellites useful in gathering land use and land cover information. The suitability of satellite remote sensing imageries in urban morphological and environmental quality modelling has also been enhanced by the imageries' wide range spatiotemporal, radiometric and spectral resolutions.

Satellite remote sensing technology has evolved in eight epochs as illustrated in Table 1. While airborne epoch began during the First and the Second World Wars to aid in military surveillance, the space-borne epoch originated from the launch of satellites such as Sputnik 1 from Russia, Explorer 1 and Television and Infrared Observational Satellite-1 (TIROS-1) for meteorological purposes by the United States 
of America at the end of 1950s [26, 51]. At the peak of the cold war, spy satellites such as Corona were used for military surveillance. This marked the era of spy satellite remote sensing which in concert with airborne and space-borne epochs created foundation for the application of the technology in resource management [29]. Initial meteorological satellites notably the Geostationary Operational Environmental Satellite (GOES), National Oceanic and Atmospheric Administration (NOAA) and Advanced Very High-Resolution Radiometer (AVHRR) provided digital data which were digitally analysed [57]. The Landsat era began with the launch of Earth Resources
Technology Satellite (Landsat-1) which had on board MultiSpectral Scanner (MSS) sensors in the year 1972. This was succeeded by Landsat- 2 and 3 both of which had MSS sensors on board and Landsats-4 and 5 mounted with Thematic Mapper (TM) sensors. While Landsat-6 failed during launch, Landsat-7 was successful and mounted with Enhanced Thematic mapper plus (ETM+) sensor. The Landsat- 8 mounted with Operational Land Imager (OLI) was launched in the year 2011. The Landsat era has equally witnessed good sun-synchronous satellites such as Systeme Pour l'Observation de Ia Terre (SPOT) of France and the Indian Remote Sensing Satellite (IRS) of India [6].

Table 1. Satellite Sensor Characteristics.

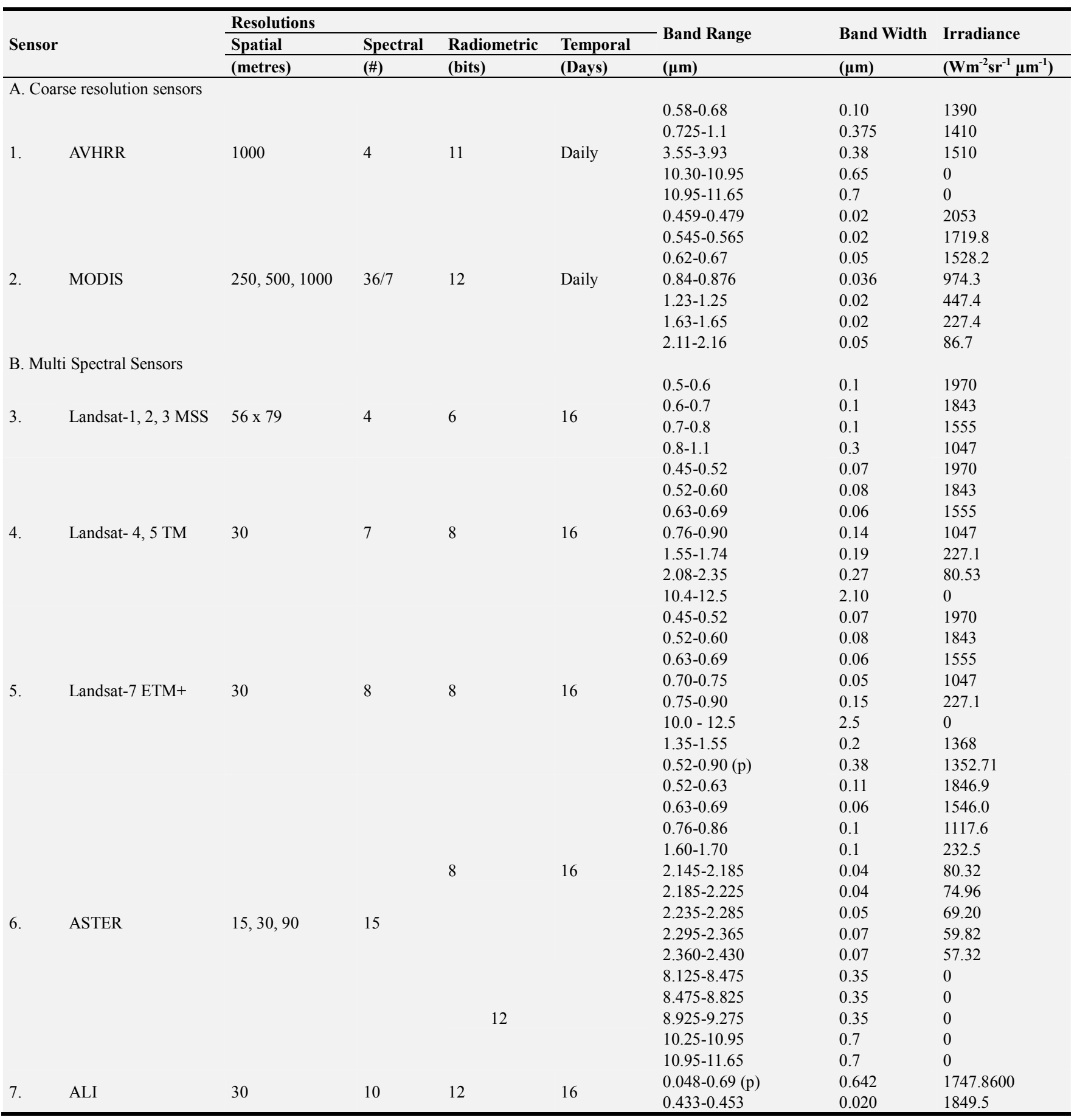




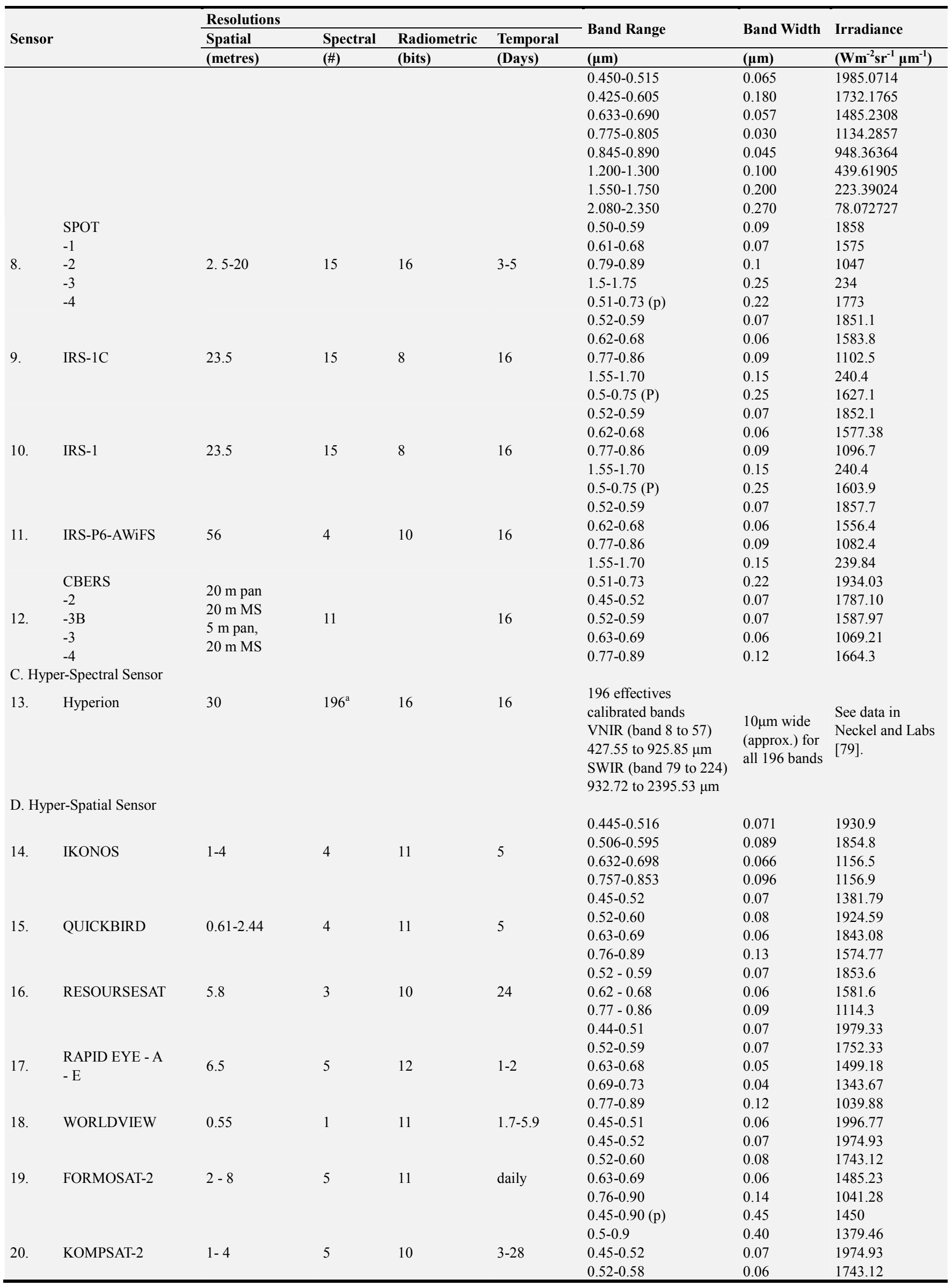




\begin{tabular}{|c|c|c|c|c|c|c|c|}
\hline \multirow{3}{*}{ Sensor } & \multicolumn{4}{|c|}{ Resolutions } & \multirow{2}{*}{ Band Range } & \multirow{2}{*}{ Band Width } & \multirow{2}{*}{ Irradiance } \\
\hline & Spatial & Spectral & Radiometric & Temporal & & & \\
\hline & (metres) & (\#) & (bits) & (Days) & $(\mu \mathrm{m})$ & $(\mu \mathrm{m})$ & $\left(\mathrm{Wm}^{-2} \mathrm{sr}^{-1} \mu \mathrm{m}^{-1}\right)$ \\
\hline & & & & & $0.59-0.63$ & 0.04 & 1485.23 \\
\hline & & & & & $0.76-0.90$ & 0.14 & 1041.28 \\
\hline
\end{tabular}

Note: $\mathrm{a}=$ Of the 242 bands, 196 are unique and calibrated. These are: (A) Band $8(427.55 \mu \mathrm{m})$ to band $57(925.85 \mu \mathrm{m})$ that are acquired by visible and nearinfrared (VNIR) sensor; and (B) Band $79(932.72 \mu \mathrm{m})$ to band $224(2395.53 \mu \mathrm{m})$ that are acquired by short wave infrared (SWIR) sensor, b = First band is panchromatic, the rest Multi-Spectral

Source: Assefa et al., [6]

The Landsat series, SPOT and IRS were succeeded by the Earth Observing Satellite systems which were launched in the year 1999 starting with Terra satellites. The epoch is characterised by reduced global coverage, geo-rectification at satellite reflectance alongside easy and mostly free access to data [6]. Other satellites in this series include the Terra-Aqua mounted with Moderate Resolution Imaging Spectroradiometer (MODIS) sensors and instruments for measuring tropospheric pollution. The satellites of this era has availed processed data for land use and land cover analysis which are imperative in urban morphological and environmental quality monitoring, thus marking the most significant era for the utility of satellite remote sensing technology in urban morphological studies, resource and environmental management.

Other innovations in the satellite remote sensing technology which emerged in the millennium era include Earth Observing- 1 and Advanced Land Imager (ALI) mounted with spaceborne hyperspectral sensors. The era has witnessed the incorporation of geospatial information into limited liability companies and the acquisition of imageries in very high spatial resolutions of less than 5 metres as exemplified by IKONOS and Quickbird satellites. The epoch has also witnessed the acquisition of data within constellation framework as exemplified by Rapid-eye satellite constellation consisting of five satellites with daily five band global coverage at 6.5 metres resolution. Other innovations of the era include the introduction of micro-satellites as either stand alone or constellation satellites for monitoring urbanisation and disaster management. The micro-satellites were mainly designed and launched by Surrey Satellite Technology Ltd for Turkey, Nigeria, China, United States Geological Survey and United Kingdom among others. The era has also witnessed the launch of the Google Earth, which has enabled access to high spatial resolution imageries [94]. Currently, space-borne remote sensing satellites using radar technology such as the European Radar Satellite (ERS), Japanese Earth Resources Satellite (JERS), Radarsat, Advanced Land Observation Satellite (ALOS) and the Shuttle Radar Technology Mission (SRTM) are used for gathering data for digital elevation modelling.

Despite satellite remote sensing providing data at appropriate spectral and radiometric resolutions, synoptic, accurate and regular coverage at lower unit costs, the application of the technology in urban landscape is fairly a recent development. This is occasioned by the nature of urban settlements consisting of complex surfaces each exhibiting unique radiative, thermal, moisture and aerodynamic properties. However, with the advent of highresolution imageries, urban remote sensing has slowly taken root [110]. At initial stages, the utility of satellite remote sensing in urban settlements was mainly confined to environmental monitoring and modelling of land use, land cover mapping and change detection with accuracies which were hardly greater than $80 \%$ [107]. This was occasioned by mixed-pixel phenomenon in satellite remote sensing where different land uses and land covers exhibit closer spectral signatures within a single pixel. This has since been emolliated by fuzzy approach to land use and land cover classifications in which each pixel is assigned a class membership as opposed to a single label [103]. Towards this end, vegetation, impervious surface and soil classification model which assumes that urban land cover is heterogeneous permutation of the mentioned elements remains the best classification model for urban satellite remote sensing [90].

Since the launch of Landsat-1 in the year 1972, researchers have utilized Landsat and other satellite imageries in identifying, classifying, mapping and monitoring of urban land uses, land covers, environmental resources, hydrological and watershed management due to spectral alterations occasioned by the changes [67, 68, 101]. Macleod and Congalton [62] posit that aspects of change that are important when monitoring urban morphological changes are the nature, pattern and quantification of the changes. The eleven change detection algorithms commonly used are mono-temporal change delineation, delta or post classification comparisons, multidimensional temporal feature space analysis, composite analysis, image differencing, multi-temporal linear data transformation and change vector analysis. Others are image regression, multi-temporal biomass index, background subtraction and image ratio, all of which requires augmentation with field surveys for increased accuracy [22, 41, 93, 100]. For instance, in the year 1982 waste land mapping of India was carried out on 1:1 million scale by National Remote Sensing Agency (NRSA) using Landsat MSS imagery. Mahavir and Galema [63] used SPOT imagery to monitor land use and land cover dynamics of Chiangmai Thailand by visually interpreting panchromatic print of the imagery and achieved $92.7 \%$ accuracy. The study concludes that for a rapid and quantitative assessment of land use and land cover dynamics, SPOT imageries are accurate. Dimyati and Kitamura [27] comparatively used Landsat-MSS and SPOT-HRV imageries to analyze the growth of Samarinda city in Indonesia for the years 1984 and 1987 and the study's accuracy legitimized the utility of geospatial technology.

Brouwer et al [17] further validated the utility of the 
technology through the assessment of the urban growth of Barranquilla-Colombia using SPOT imageries of the city for the years 1982 and 1986. The findings of the study enabled the policy makers to redirect urban development resources equitably. While the United States Geological Survey produced 1:250,000 scale land use and land cover maps of Alaska using Landsat MSS imagery in the year 1985, the State of Maryland Health Resources Planning Commission used Landsat TM imagery to create a land use and land cover dataset for inclusion in Maryland Geographic Information Database [36, 28]. In the year 1992, the Georgia Department of Natural Resources undertook land use and land cover mapping using Landsat TM imagery [32]. Prior to this, Odenyo and Pettry [81] undertook land use and land cover mapping of Virginia city using Landsat MSS imagery and achieved $88 \%$ overall accuracy.

Recent studies have increasingly utilised geospatial technology to model the relationships existing between urban morphology and the environmental quality parameters of surface temperature and air quality. Such studies include Oyugi et al [85], Screenivasulu et al [89], Reis [86], Mishra et al [71], Billah and Rahman [12], Sundarakumar et al [97], Mahmood et al [64], Tan et al [98], Weng [105], Streutker [95], Nichol et al [80], Weng [106], Lo and Quattrochi [60], Hawkins et al [49], Weng and Yang [108], Borghi et al [13] and Hirano et al [50] among others. Voogt and Oke [102] noted that improvements in the spatial, radiometric, spectral and temporal resolutions of satellite sensors will continue to enhance the utility of remote sensing in the study of urban morphology and climatology. This is supported by Arnis et al [3] who posit that urban morphological and environmental quality parameters such as land use, land cover and surface temperatures can efficiently and effectively be derived from satellite remote sensing imageries to corroborate the effects of anthropogenic activities on urban environmental quality.

Despite geospatial techniques being vital in rapid and detailed urban morphological surveys, mapping, modelling and monitoring of urban environmental quality, the accuracy of such analysis depends on the quality of the imagery, the classification schema and procedures used as well as the technical and indigenous knowledge of the analyst on the study area. Daniel [24] undertook a comparative study on land use and land cover change detection methods and concludes that there are merits in each method and that no single approach can wholly solve the inaccuracies associated with geospatial techniques. Sentiments have also been expressed on classification schema; that no single classification schema can be universally applied in all the study scenarios, thus there is a need to device a schema which represents a study area [78]. To date, the best attempt at developing a general-purpose schema compatible with remote sensing data has been that of Anderson et al [2] and majority of the studies are a modification of the attempt.

The improvements in resolutions, three-dimensional laser scanning and advancements in digital image processing technology have endured the utility of geospatial technology in urban master planning. Indeed the imageries procured by multispectral aerial photography and high spatial resolution satellites such as IKONOS and Quickbird have been used as sources of data for urban master planning. With either digital or analogue processing, land use and land cover mapping that forms the basis for urban master planning and monitoring, can be undertaken. Remote sensing data has also been utilised in the assessment of urban environmental quality and traffic analysis. The planning of Beijing city in the year 1980 utilised a combination of multispectral aerial photographs, satellites and GIS to acquire, manipulate and store information on soil and water resources, geological base, ecological conditions, urban heat island effects, land uses and other amenities [113]. Since the year 1988, Shanghai city in China has also undertaken three surveys using geospatial techniques to derive information for urban master planning and renewal [20]. Similarly, in the year 1999, China's Ministry of Land Resources initiated a project called the National Land Use Monitoring that utilised a combination of China made satellite, Landsat MSS and TM as well as SPOT imageries to monitor land use and land cover changes of 66 cities with a population of 500,000 [112]. This corroborates that remote sensing imageries if augmented with GIS is instrumental in the analysis of a city's physiographical and climatological conditions, resource distribution, spatial layout, road network, land use, land cover and postulation of urban sprawl, all of which are imperative in the preparation of urban master plans. While the spatiotemporal analysis of urban growth has utilised medium resolution satellites such as Landsat and SPOT imageries, high resolution imageries notably SPOT 5, Quickbird and IKONOS have been utilised for detailed spatiotemporal analysis of land use changes in the inner city as well as updating base maps. High resolution imageries are also imperative in monitoring the adherence to urban development control standards which entail the extraction of building densities and distances between buildings. Further, high resolution imageries with stereovision capabilities are significant for urban terrain and three-dimensional modelling. Geospatial techniques are also important in the identification of illegal developments, which is an aspect of urban plan compliance monitoring. This is undertaken through comparative analysis on a regular basis, of the planned and imagery data aided by the overlay function of the GIS [114].

The unique spectral signatures of surfaces in the visible, infra-red and thermal bands has enabled land cover classification, calculation of surface temperatures and Normalised Difference Vegetation Index (NDVI) to heighten the potentials of geospatial technology in urban watershed mapping and estimation of hydrological parameters. This is corroborated by the utility of Landsat $5 \mathrm{TM}$ and Landsat 7 ETM + in the computation of the variations in the surface area of the Devils Lake between the years 1991 to 2003. Radiative Transfer Method which proceeds through the extraction of Digital Numbers (DNs) from a Thermal Infra-Red (TIR) imagery, the conversion of DNs to spectral radiance, calculations of the satellite temperature values of the imagery, the NDVI, the emissivity value from the NDVI and the 
surface temperatures using different functions provided by Oyugi et al [85] has been used in estimating urban surface temperature values.

\subsection{The Frontiers of Geospatial Technology in the Management of Urban Morphological Changes}

The slow uptake of geospatial technology in urban planning has been occasioned by disharmony in the resolutions provided by various satellite imageries and the knowledge gap in digital image processing among Urban Planners. This necessitates reliance on other experts with limited knowledge on urban planning standards, leading to compromised outputs. However, this has been changing and it is evident that the technology is gaining acceptance and finding a niche in the curriculum of several academic disciplines alongside national government agencies and research institutions. The development which is postulated to continue has been aided by wireless broadband internet, cell phones and innovations in computer technology. This presents an opportunity for an objective look at positioning geospatial issues in both academic and government agencies. For example, in academia the teaching of the technology is domiciled in the curricula of Geography, Geomatic Engineering and Natural Resource Departments among others, with focus of the curriculum being the acquisition of expertise in data input and manipulation largely on desktops through scanning, digitization and conversion of the data into different file formats, systems and sharing between various softwares. However, outputs of such manipulations are not necessarily transformed into tangible policies. This has only been successful in addressing the limited scope of issues requiring the utility of the technology but not the integration of the information into mainstream Information and Communication Technology. Ideally, this requires a coordinated leadership to build foundation for the uptake of the technology through web-based interoperability to facilitate data sharing and integration of the same with ancillary data. This is significant in furthering researches in urban morphology and policy enactment which rely on data from different sources. The non-interoperability which has characterised the geospatial data domain for decades has ensured that data are often collected in duplication, utilized and discarded - not maintained online for posterity and sharing. The leadership should mimic the interoperability standards providing organizations such as the ISOs-TC211 committee on Geographic Information, Geomatics and Open Geospatial Consortium and other organizations instrumental in the creation of World Wide Web that enables data interoperability.

The primacy of interoperability of geospatial data in human settlement development and management compels the academia, research institutions and government agencies charged with the responsibility of urban management to network datasets in their jurisdictions into web services complete with schema and metadata. Many benefits accrue from the endeavour, supreme among which is the improved opportunities for multidisciplinary studies on population growth, relocation of land use activities, urban form and sprawl, environmental quality and disaster management, water, food and energy securities, global warming and climate change among others. The automation facilitated by web-based geospatial data with online search capabilities is likely to reduce the amount of time spent on data acquisition. Further to enhancing the ability to repurpose data utility for various investigations with reduced redundancy, building scenario for scientific debates and discoveries on the correlations existing between spatial phenomena, the endeavour will also enable researchers to have increased time for research and dissemination of the findings.

The geospatial software vendors and the industry at large have significantly contributed to Information and Communication Technology development as corroborated by Open Access geospatial data and information interoperability. However, this should further be supported by the academia through designs of innovative curriculum which creates diversity in career path, national competitive advantage, emergence of new niches of urban-based geospatial studies and competency in addressing urbanisation problems. Indeed, there is need for creation of academic departments and research centres anchored on geodesy and other positioning technologies, including GPS, reinforced with geospatial semantics and ontology incorporating names, meanings, measurements and relationships of urban entities which have co-evolved with the open standards. The interoperability also requires high performance computers, well developed databases, broad-band internet and mobile computing networks to facilitate real time data acquisition and simulation. Finally, there is need for the development of user interface and workflow management for seamless interaction with the digital world and to facilitate urban morphological, environmental quality and spatial relationship modelling.

The governments equally have a mandate in popularising the utility of geospatial technology through the creation of National Geographic Data Committees to oversee the implementation of open geospatial consortium, development of geospatial data, metadata and encoding standards as well as institutionalisation of National Spatial Data Infrastructure to enhance web-based data services and interoperability [83]. The spatial data infrastructure is imperative in aiding the municipal utility departments, public transportation companies, land registries, Urban Planners, Landscape Conservationists and the academia to access data for various purposes at reduced costs. In lieu of the above, governments in collaboration with software vendors, the industry and academia should create a favourable environment and introduce web-based geospatial data policies, procedures and regulations tackling liability, privacy, intellectual property rights and national security. These will emolliate the legal and commercial obstacles hindering the publications and sharing of data.

\section{Conclusion and Policy Implications}

The advances registered in geospatial technology such as 
the availability of geospatial data in multiple sensors with high resolutions in the last decade have been phenomenal in aiding quantitative urban morphological studies and formulation of sustainable urban management policies. Other achievements in geospatial technology have been in the areas of harmonisation and synthesis of data from different sensors alongside satellite remote sensing constellation which has enabled global coverage in 13 days [33]. This facilitates integration of multi-source and multi-date data for the generation and prediction of the trends, nature, patterns, magnitude and the impact of urban morphology on environmental quality. Further, the emergence of high resolution micro-satellite imageries designed to gather data on specific orbital scope such as specific urban areas has emerged as the most innovative technology for capturing urban morphological and environmental quality attributes. The cited advantages should motivate the governments, financial institutions, academia, the industry and research institutions to provide enabling environments upon which the technology can be adopted for the solution of urbanisation problems, food and water security as well as global warming and climate change. This review demonstrates that spatial information is crucial for urban morphological and management studies. However, since there is a serious dearth of accurate spatial information and data banks, particularly in the developing nations, the challenge can be alleviated through planned interventions in sustained use of geospatial techniques for periodic surveys and updating of urban morphological changes and integrating the changes with conventional in-situ techniques and other ancillary data. However, the accuracy, validity and reliability of the byproducts of such operations are dependent on the quality of the datasets used. For urban management, this should be augmented with the adoption of a combination of proactive management techniques, innovative urban design and conservation aimed at shifting cities onto sustainable development trajectory.

\section{References}

[1] Alonzo, W (1964). Location and Land Use. Harvard University Press, Cambridge, MA.

[2] Anderson R, Hardy EE, Roach JT, Witmer RE (1976). A Land Use and Land Cover Classification System for Use with Remote Sensor Data. USGS Professional Paper 964, Sioux Falls, SD, USA.

[3] Arnis A, Shattri M, Wong TH (2003). Rule based classification for Urban Heat Island Mapping. Proceedings of the $2^{\text {nd }}$ FIG Regional Conference Marrakech, Morocco, December 2-5, 2003.

[4] Arvind CP, Nathawat MS (2006). Land Use and Land Cover Mapping through Digital Image Processing of Satellite Data A case study from Panchkula, Ambala and Yamunanagar Districts, Haryana State, India.

[5] Asoka GWN, Thuo ADM, Bunyasi MM (2013). Effects of Population Growth on Urban Infrastructure and Services: A
Case of Eastleigh Neighborhood Nairobi, Kenya. Journal of Anthropology and Archaeology, 1 (1), 41-56.

[6] Assefa M, Melesse 1, Qihao W, Prasad ST, Gabriel BS (2007). Review Remote Sensing Sensors and Applications in Environmental Resources Mapping and Modelling, Sensors, 7: 3209-3241.

[7] Babarinde, J. A. (1995), Industrial Migration and Residential Relocation Decisions in Metropolitan Lagos, Nigeria, An Unpublished $\mathrm{PhD}$ Thesis, Department of Geography, Faculty of the Social Sciences, University of Ibadan, Ibadan, Nigeria.

[8] Benti BB, Aneseyee AB, Garedew E (2017). Land Use and Land Cover Changes and its Socio-Economic Impact on Local Community in Bako Tibe District, West Shewa Zone of Oromia National Regional State, Ethiopia. Journal of Advances in Life Science and Technology, Vol 58, 2017.

[9] Bibby PR, Shepherd JW (1990). Rates of urbanisation in England 1991-2001. London, Her Majesty's Stationery Office.

[10] Bicík I, Jelecek L, Stepánek V (2001). Land Use Changes and their Societal Driving Forces in Czechia in $19^{\text {th }}$ and $20^{\text {th }}$ Centuries. Land Use Policy, 18 (1): 65-73.

[11] Billah M, Gazi AR (2004). Land Cover Mapping of Khulna City Applying Remote Sensing Technique. Proc. 12th Int. Conf. on Geoinformatics/Geospatial Information Research: Bridging the Pacific and Atlantic, University of Gävle, Sweden, 7-9 June 2004.

[12] Billah M, Rahman GA (2004). Land Cover Mapping of Khulna City Applying Remote Sensing Technique. Bangladesh University of Engineering and Technology, 2 (1), 46-59.

[13] Borghi S, Corbetta G, De Biase L (2000). A Heat Island Model for Large Urban Areas and Its Application to Milan, Geophysics and Space Physics, 23: 547-566.

[14] Bourne, LS (1976). Urban Structure and Land Use Decisions. Annals of the Association of American Geographers, 66 (4): 531-535.

[15] Broitman D, Koomen E (2015). Residential Density Change: Densification and Urban Expansion. Computers, Environment and Urban Systems, 54: 32-46.

[16] Broome FR, Meixler DB (1990). The TIGER Data Base Structure. Cartography and Geographic Information Systems. 17 (1): 39-47.

[17] Brouwer H, Valenzuela CR, Valencia LM, Simons K (1990). Rapid Assessment of Urban Growth Using GIS-RS Techniques. ITC Journal, 5: 233-235.

[18] Burgess EW (1925). The Growth of the City: An Introduction to a Research Project. American Sociological Society, 18: 85-97.

[19] Chang, KT (2008). Introduction to Geographical Information Systems. New York: McGraw Hill.

[20] Cheng Z, Sun J, Jiang Z (1996). Study and see forward to comprehensive investigation of aerial remote sensing of Shanghai city, Remote Sensing for Land and Resources, No. 1, March 1996.

[21] Clarke KC (1986). Advances in Geographic Information Systems, Computers, Environment and Urban Systems, Vol. 10: $175-184$. 
[22] Coppin P, Bauer M (1996). Digital Change Detection in Forest Ecosystems with Remote Sensing Imagery. Remote Sensing Reviews. 13: 207-234.

[23] Dangermond, J (2009). Foreword. In Scholten H. J, Manen van, $\mathrm{N}$ and Velde, van de R (Eds) Geospatial Technology and the Role of Location in Science, Springer Dordrecht Heidelberg London New York.

[24] Daniel K (2002). A comparison of Land Use and Land Cover Change Detection Methods. ASPRS-ACSM Annual Conference and FIG XXII Congress.

[25] De Groot RS, Wilson MA, Boumans RM (2002). A Typology for the Classification, Description and Valuation of Ecosystem Functions - Goods and Services. Ecological Economics, 41 (2): 393-408.

[26] Devine R (1993). The Sputnik Challenge, Oxford University Press, New York.

[27] Dimyati M, Kitamura T (1990). The Application of Digital Image Processing for Residential Variation Analysis Using Landsat MSS and SPOT HRV data. Asia-Pacific Remote Sensing Journal, 2 (2): 33-41.

[28] Dimyati P (1995). An Analysis of Land Use/Land Cover Change Using the Combination of MSS Landsat and Land Use Map - A Case Study of Yogyakarta, Indonesia, International Journal of Remote Sensing, 17 (5): 931- 944.

[29] Dwayne AD, Logsdon JM, Latell B (1988). The Story of the Corona Spy Satellites. In Dwayne AD. Logsdon JM and Latell B (Eds) Eye in the Sky, Smithsonian Books, Washington, DC.

[30] Edward MG (1971). An Experiment in the Development of Critical Thinking. Bureau of Publications, New York.

[31] Emmanuel MR (2005). An Urban Approach to Climate Sensitive Design; Strategies for the Tropics. London, Spon Press.

[32] ERDAS (1992). Mapping State of Georgia DNR, 4 (1), ERDAS, Inc, Atlanta, GA New York.

[33] Fátima-Loureiro de Matos (2018) Urban morphology: An introduction to the study of the physical form of cities, Journal of Urban Affairs, 40: 8, 1197-1199.

[34] Finger M (2016). Introduction to Urban Infrastructure: Innovative Governance of Large Urban Ecosystems. Retrieved from: http://iglus.org/wp-content/uploads/2016/02/B1S3-Themain-dimensions-of-urban-infrastructures. pdf on $18^{\text {th }}$ August, 2018.

[35] Firey HM (1974). The Political Economy of Ethnic Change. American Journal of Sociology, 79:1151-78.

[36] Fitzpatric L (1987). Producing Alaska Interim Land Cover Maps from Landsat Digital and Ancillary Data. In Proceedings of the $11^{\text {th }}$ Annual William T. Pecora Memorial Symposium: American Society of Photogrammetry and Remote Sensing: 339-347.

[37] Ford Foundation (1993). Urban Research in the Developing World. Report Presented in the Final Meetings, Cairo, February $14-18$.

[38] Foresman T (1997). The History of GIS (Geographic Information Systems): Perspectives from the Pioneers. London, Prentice Hall PTR.
[39] Fu P, Sun J (2010). Web GIS: Principles and Applications. ESRI Press. Redlands, CA.

[40] Gallion P (1963). Urban Pattern, Columbia University Press, New York.

[41] Gastellu-Etchegorry JP (1988). Remote Sensing with SPOT: An Assessment of SPOT Capability in Indonesia. Gadjah Mada University Press, Yogyakarta.

[42] Gilliland J, Gauthier P (2006). The Study of Urban Form in Canada. Urban Morphology, 10 (1): 51-66.

[43] Glaeser EL, Ward BA (2009). The Causes and Consequences of Land Use Regulations: Evidence from Greater Boston. Journal of Urban Economics, 65 (3), Elsevier, London.

[44] Goodchild, MF (2010). Twenty years of progress: GIScience in 2010. Journal of Spatial Information Science, Number 1 (2010): 3-20.

[45] Guttenberg AZ (1960). Urban Structure and Growth. Journal of the American Institute of Planners, 26: 104-110.

[46] Hall AC (1977). Dealing with Incremental Change: An Application of Urban Morphology to Design Control. Journal of Urban Design, 2: 221-39.

[47] Harris CD, Ullman EL (1945). The Nature of Cities. Annals of the American Academy of Political and Social Science 242: 7-19.

[48] Hartshon TA (1980). Interpreting the City: An Urban Geography. London, John Wiley \& Sons.

[49] Hawkins TW, Brazel AJ, Stefanov WL, Bigler W, Saffell EM (2004). The Role of Rural Variability in Urban Heat Island Determination for Phoenix, Arizona. J. Appl. Meteorol., 43: 476-486.

[50] Hirano Y, Yasuoka Y, Ichinose T (2004). Urban Climate Simulation by Incorporating Satellite-Derived Vegetation Cover Distribution into a Mesoscale Meteorological Model. Theor Appl Climatol 79: 175-184.

[51] House FB, Gruber A, Hunt GE, Mecherikunnel AT (1986). History of satellites missions and measurements of the Earth Radiation Budget (1957-1984); Reviews of geophysics, 1986; 24, pp. 357-377.

[52] Howard E (1898). Originally published in 1898 as To-Morrow: A Peaceful Path to Real Reform and reissued in 1902 under its present title, Garden Cities of Tomorrow. London, Routledge.

[53] Hoyt H (1939). The Structure and Growth of Residential Neighbourhoods in American Cities. Washington DC; Federal Housing Administration.

[54] Kerry A (2003). Geographic Information Systems in Food Security and Demining Programs. Humanitarian Exchange, (24): 31-33.

[55] Kirigwi ZM (2008). Effects of Rapid Urbanization on Land Use in the Nairobi Urban Fringe: A Case of Ruaka, Kiambu. Unpublished Bachelor of Urban and Regional Planning Project, University of Nairobi, Kenya.

[56] Knox P, Linda MM (2012). Urbanization: An Introduction to Urban Geography, Prentice Hall, London.

[57] Kramer (2002). Kramer, H. J. Observation of the Earth and its Environment: Survey of Missions and Sensors, Springer Verlag: Berlin. 
[58] Kumar S, Sangwan RS (2013). Urban Growth, Land Use Changes and Its Impact on Cityscape in Sonipat City Using Remote Sensing and GIS Techniques. International Journal of Advanced Remote Sensing and GIS, Volume 2, Issue 1: 326332.

[59] Lipton M (1977). Why Poor People Stay Poor: A Study of Urban Bias in World Development. Canberra, Australian National University Press.

[60] Lo CP, Quattrochi, DA (2003). Land-Use and Land-Cover Change, Urban Heat Island Phenomenon and Health Implications: A Remote Sensing Approach. Photogrammetric Engineering \& Remote Sensing, 69 (9): 1053-1063.

[61] Lo CP, Yang X (2002). Drivers of Land Use/Land Cover Changes and Dynamic Modelling for the Atlanta, Georgia Metropolitan Area. American Society of Photogrammetry and Remote Sensing. Vol 68 No 10.

[62] Macleod K, Congalton P (1998). A Quantitative Comparison of Change Detection Algorithms for Monitoring Eelgrass from Remotely Sensed Data. Photogrammetric Engineering \& Remote Sensing. 64 (3): 207-216.

[63] Mahavir T, Galema M (1991). Monitoring Urban Growth Using SPOT Images and Aerial Photographs. ITC Journal 2, 63-69.

[64] Mahmood R, Pielke RKG, Ni YD, Bonan G, Lawrence R, Mcnider R, Mcalpine C, Etter A, Gameda S (2010). Impacts of Land Use/Land Cover Change on Climate and Future Research Priorities, American Meteorological Society, January 2010.

[65] Maina JK (2010). Re-Organization of Peri-Urban Residential Growth in Ruaka -Nairobi, Kenya. Unpublished Bachelor of Urban and Regional Planning Project, University of Nairobi, Kenya.

[66] Maliene V, Grigonis V, Palevičius V, Griffiths S (2011). Geographic information system: Old principles with new capabilities. Urban Design International. 16 (1): 1-6.

[67] Martin LRG (1986). Change Detection in the Urban Fringe Employing Landsat Satellite Imagery. Plan Canada 26 (7): 182-190.

[68] Mather, PM (1999). Land cover classification revisited. In Advances in Remote Sensing and GIS, Atkinson, P. M., Tate, N. J., Eds.; John Wiley \& Sons: New York.

[69] Mengistu DA, Salami AT (2007). Application of Remote Sensing and GIS in Land Use/Land Cover Mapping and Change Detection in a Part of South Western Nigeria. African Journal of Environmental Science and Technology 1 (5): 99109.

[70] Miller G (1994). Living in the Environment. Wadsworth, Belmont, CA.

[71] Mishra A, Karwariya S and Goyal S (2012). Land Use /Land Cover Mapping of Chhatarpur District, Madhya Pradesh, India Using Unsupervised Classification Techniques. OISR Journal of Engineering, Vol 2 Issue 10: 51-56.

[72] Moudon AV (1994). Getting to Know the Built Landscape: Typomorphology. In Franck K. A and Lynda H. S (Eds), Ordering Space: Types in Architecture and Design. New York, Van Nostrand Reinhold.

[73] Moudon AV (1997). Urban Morphology as an Emerging
Interdisciplinary Field, Urban Morphology 1: 3-10.

[74] Mundia CN, Aniya M (2005). Analysis of Land Use/ Cover Changes and Urban Expansion of Nairobi City Using Remote Sensing and GIS. International Journal of Remote Sensing, 26 2831-2849.

[75] Musa MK, Odera PA (2015). Land Use/Land Cover Changes and their Effects on Agricultural Land: A Case Study of Kiambu County - Kenya. Kabarak Journal of Research \& Innovation, Vol 3 (1).

[76] Museleku EK (2013). An Investigation into Causes and Effects of Agricultural Land Use Conversions in the Urban Fringe: A Case Study of Nairobi-Kiambu Interface. Unpublished Master of Valuation and Property Management Project, University of Nairobi, Kenya.

[77] Mwathi MP (2016). Effects of Land Use and Land Cover Dynamics on Environmental Quality of Nairobi and its environs. Unpublished Master of Urban Management Project, University of Nairobi, Kenya.

[78] Nasreen IK (1999). Present Status of Geoinformatics Technology In Bangladesh: Special Emphasize on Implementation and Operationalisation. $2^{\text {nd }}$ International Symposium on Operationalization of Remote Sensing, ITC.

[79] Neckel H, Labs D (1984). The solar radiation between 3300 and 12500, Solar Phys., 205-258.

[80] Nichol J, Man SW, Fung C, Leung KKM (2006). Assessment of Urban Environmental Quality in A Subtropical City Using Multispectral Satellite Images, Environment and Planning B: Planning and Design 33 (1): 39-58, London, Francis \& Taylor.

[81] Odenyo VAO, Pettry DE (1977). Land Use Mapping and Machine Processing of Landsat MSS Data. Photogrammetric Engineering and Remote Sensing Journal, XLIII No 4: 311315. Virginia, USA.

[82] Oyugi MO (2018). Modelling the Effects of Urban Morphology on Environmental Quality of Nairobi City, Kenya. Unpublished Doctor of Philosophy Thesis, University of Eldoret, Kenya.

[83] Oyugi MO, Karanja FN (2014). The Need for Database and User-Interface Systems for Urban Planning. African Habitat Review, 8 (2014): 653-885.

[84] Oyugi MO, Karanja FN, Odenyo VAO (2017). Modelling the Effect of Land Use and Land Cover Variations on the Surface Temperature Values of Nairobi City, Kenya. Resources and Environment 7 (6): 145-159.

[85] Oyugi MO, Odenyo VAO, Karanja FN (2017). The Implications of Land Use and Land Cover Dynamics on the Environmental Quality of Nairobi City, Kenya. American Journal of Geographic Information System, 6 (3): 111-127.

[86] Reis S (2008). Analyzing Land Use/Land Cover Changes Using Remote Sensing and GIS in Rize, North-East Turkey. Sensors, Aksaray University.

[87] Samie A, Deng X, Chen D (2017). Scenario Based Simulation on Dynamics of Land Use-Land Cover Change in Punjab Province, Pakistan. Sustainability, 1285.

[88] Sanders P, Baker D (2016). Applying urban morphology theory to design practice, Journal of Urban Design, 21: 2, 213-233 
[89] Screenivasulu G, Jayaraju N, Kumar MP, Prasad TL (2013). An Analysis on Land Use and Land Cover Changes Using Remote Sensing and GIS: A Case Study In and Around Vempalli, Kadapa District Andhra Pradesh District, India. International Journal of Scientific Research and Publications, Vol 3 .

[90] Setiawan H, Mathieu R, Thompson-Fawcet M (2006). Assessing the applicability of the V-I-S model to map urban land use in the developing world: Case study of Yogyakarta, Indonesia. Computers, Environment and Urban Systems, 30 (4), 503-522.

[91] Shosheng P, Kutiel T (1994). Satellite Remote Sensing As a Tool in Disaster Management. Disasters, 26 (2): 140-160.

[92] Simon R, John M, Richard H, Nelson T (2000). Essential AS Geography, New York: McGraw-Hill.

[93] Singh A (1989). Digital Change Detection Techniques Using Remotely Sensed Data. International Journal of Remote Sensing. 10 (6): 989-1003.

[94] Stoney WA (2005). Guide to the Global Explosion of LandImaging Satellites; Markets and Opportunities.

[95] Streutker D (2002). Satellite-Measured Growth of the Urban Heat Island of Houston, Texas. Remote Sensing of Environment, 85: 282-289.

[96] Sullivan AO (2012). Urban Economics, New York: Irwin/McGraw-Hill.

[97] Sundarakumar K, Harika M, Begum SKA, Yamini S, Balakrishna K (2011). Land Use and Land Cover Change Detection and Urban Sprawl Analysis of Vijayawada City Using Multi-Temporal Landsat Data, International Journal of Engineering Science and Technology (IJEST), 4 (1): 170-178.

[98] Tan KC, Lim H. S, MatJafri MZ, Abdullah K (2010). Landsat Data to Evaluate Urban Expansion and Determine Land Use/Land Cover Changes in Penang Island, Malaysia, Environmental Earth Sciences, 60 (7): 1509-1521.

[99] Tomlinsons R (2012). Origins of the Canada Geographic Information System, ESRI Press, Redlands.

[100] UNESCAP/UNDP (1985). Development and Applications of Remote Sensing for Planning, Management and Decision Making. United Nations Economic and Social Commission for Asia and the Pacific/United Nations Development Programme, Bangkok.

[101] Ursula CB, Peter H, Gregor W, Iris L, Markus H (2004).
Multi-Resolution, Object-Oriented Fuzzy Analysis of Remote Sensing Data for GIS-Ready Information. Journal of Photogrammetry \& Remote Sensing, 58: 239-258.

[102] Voogt JA, Oke TR (2003). Thermal Remote Sensing of Urban Climates, Remote Sensing of Environment, 86: 370-384.

[103] Wang F (1990). Fuzzy supervised classification of remote sensing images. IEEE Transactions on Geoscience and Remote Sensing, 28 (2): 194-201.

[104] Webber A (1929). Theory of the Location of Industries. (translated by Carl J. Friedrich from Weber's 1909 book). Chicago, the University of Chicago Press.

[105] Weng Q (2001). A Remote Sensing-GIS Evaluation of Urban Expansion and Its Impact on Surface Temperature in the Zhujiang Delta, China. Int. J. Remote Sens. 22 (10): 19992014.

[106] Weng Q (2003). Fractal Analysis of Satellite-Detected Urban Heat Island Effect. Photogrammetric Engineering \& Remote Sensing, 69 (5): 555-566.

[107] Weng Q, Quattrochi DA (2006). Urban Remote Sensing; CRC Press/Taylor and Francis.

[108] Weng Q, Yang S (2004). Managing the Adverse Thermal Effects of Urban Development in a Densely Populated Chinese City. Journal of Climate and Applied Meteorology, 94: 670-581.

[109] Wingo L (1961). Transportation and Urban Land Use. The Johns Hopkins Press, Baltimore.

[110] Wu J (2008). Land Use Changes: Economic, Social and Environmental Impacts, Choices. London, Agricultural and Applied Economic Association.

[111] Xiangmei L, Wang Y, Li J, Lei B. (2016). Physical and Socioeconomic Driving Forces of Land-Use and Land-Cover Changes: A Case Study of Wuhan City, China. Discrete Dynamics in Nature and Society, Vol. 2016.

[112] Xiao Y, Wuhan QZ (2009). A review of remote sensing applications in urban planning and management in China. Conference Paper, June 2009.

[113]Zhang Q (1988). The role of remote sensing application in urban and rural planning based on the Beijing integrate aerial survey project, City Planning Review, Vol 121 (3).

[114]Zhang X, Li D, Gong J, Qin Q (2006). A change detection method of integrating remote sensing and GIS, Geomatics and Information Science of Wuhan University, Vol 31 (3). 